\title{
DETERMINATION OF ELECTROMAGNETIC RADIATION EMITTED BY TELECOMMUNICATION EQUIPMENT OF TRANSMISSION CENTERS
}

\author{
Oleksandr M. Naumchuk \\ National University of Water Management and Nature Resources Use, Rivne, Ukraine
}

Abstract. Determining and forecasting of environmental influence of telecommunication equipment that is a source of electromagnetic radiation is still an actual challenge. The approach proposed enables to assess an impact of wide spectral electromagnetic sources on environment as well as to elaborate practical means of minimizing their influence.

Keywords: wide spectral electromagnetic sources, cellular network, antenna, base station, frequency, spectral density, voltage

\section{WYZNACZENIE PROMIENIOWANIA ELEKTROMAGNETYCZNEGO URZĄDZEŃ KOMUNIKACYJNYCH CENTRÓW PRZESYLOWYCH}

\begin{abstract}
Abstrakt. Wyznaczenie $i$ prognozowanie wplywu urządzeń komunikacyjnych będących źródtami różnoczęstotliwościowego promieniowania elektromagnetycznego na otaczajace środowisko jest problemem aktualnym. Zaproponowane podejście pozwala ocenić wpływ promieniowania elektromagnetycznego źródel różnoczęstotliwościowych na otaczające środowisko i opracować praktyczne sposoby na jego zmniejszenie.
\end{abstract}

Słowa kluczowe: źródła różnoczęstotliwościowego promieniowania elektromagnetycznego, sieć komórkowa, antena, stacja bazowa, częstotliwość, gęstość spektralna, napięcie

\section{Introduction}

Determination and forecasting of environmental influence of telecommunication equipment that is a source of electromagnetic radiation will enable to propose specific means of its reduction. The main aim of the paper is assessment of influence factors of multispectral electromagnetic radiation on environment.

Determination of parameters to be measured when sources of electromagnetic radiation were active was done for different frequency ranges, separately for each band. In particular it has to be taken into account that television transmitting devices operates at different frequencies and the measurements have to be made for both nearer and farther zone of the device.

In most cases, the amount of electromagnetic radiation emitted separately by various radio devices does not exceed its maximum limit values. However, an increasing number of these devices in a single object, especially of different kinds and frequencies (TV, radio, CDMA, GSM) often results in exceeding the total limiting values for given distances and heights. Therefore, practical works have been proposed, particularly constant monitoring of electromagnetic field combined with the frequency analysis of sources of radiation.

For given sources, spectral density of electromagnetic radiation of different frequency has been determined as well as the necessary limitations for adjacent sites. As a result, methods of narrowing. The results permit to predict the electromagnetic situation from similar sources and indicate a few practical steps to reduce their harmful effects.

\section{Statement of the problem and its relationship to important scientific and practical tasks}

Mechanism of the influence of electromagnetic radiation on living organisms currently is not sufficient. There are several hypotheses to explain the biological effects of electromagnetic field. Basically, they all boil down to induce currents in tissues and to effect cellular structures, especially in the membrane.

It is believed that under the influence of electromagnetic fields (EMF) the rate of diffusion through cell membranes, as well as orientation and confirmation of biological macromolecules and the state of the electronic structure of free radicals may change [7, 9].

In recent years tangible a broad scientific and public interest to the problem of effects of electromagnetic radiation on the environment, both in Ukraine and abroad. Reports from the World Health Organization (WHO) provided one of the main priorities to this problem [7], but a common approach to solve this problem has not proposed yet. For example, in many countries are quite different indicators of maximum permissible levels (MPL) of electromagnetic radiation. Thus, in Ukraine MPL is set in $0,025 \mathrm{~W} / \mathrm{m}^{2}$, in Russia and Belarus $0,1 \mathrm{~W} / \mathrm{m}^{2}$, and in the Scandinavian countries $1 \mathrm{~W} / \mathrm{m}^{2}$.

Due to the impact of the electromagnetic field, the condition of biological objects changes. This can be evident in the decrease of motion activity and survival rate of microorganisms, increase of their death rate, deterioration of tissue regeneration, impaired embryonic and larvae development, reduction of biochemical reactions, metabolic disorders, reduction of the energy potential of all vital body systems.

The problem is compounded by the fact that the intensity of electromagnetic radiation is increasing every year, this is due to: construction of new and reconstruction of existing cellular base stations, reconstruction of transmission centers, facilities for radio navigation and radiolocation, stations of satellite communications, intensive development of wireless access to the Internet and local networks, and so on.

Therefore, the effect of electromagnetic fields on the environment, including living organisms, in the last 30 years has grown and became the subject of many scientific studies $[3,5]$.

\subsection{Analysis of recent research and publications, which discuss current issues}

First study of the influence of electromagnetic fields on the human nervous system was made by Professor Y.A. Holodov back in the $60 \mathrm{~s}$. As a result of long-term observations a direct influence of electromagnetic fields on brain, neurons' membranes, memory and conditional reflex activity were founded [8].

Some model experiments demonstrated possibility of weak electromagnetic fields influence on the nerve cells synthesis. Results show distinct changes of pulsation of cortical neurons, leading to disruption of transmission of information in more complex structures of the brain.

In general, changes at the cellular level, due to EMF, occur for the following reasons $[2,9]$ :

1) The electromagnetic field affects charged particles, as a result, the energy of the field at the cellular level become another form of energy. Atoms and molecules in an electric field polarized and oriented in the direction of the magnetic field distribution

2) After the impact of external electromagnetic fields in electrolytes, which are the basis of tissue of living organisms, ionic currents arise. Alternating electric field causes tissue heating due to variable polarization and due to the occurrence of conduction currents.

3) Emergence of heat effect due to the absorption of electromagnetic fields, moreover, the greater field strength and the time of its action, the more pronounced those effects. To the value of $0.00001 \mathrm{~W} / \mathrm{m}$, which is conventionally accepted 
as a threshold for heat, excess of heat is removed through the mechanism of thermoregulation. At the same time, the most sensitive to overheating are such organs: eyes, brain, kidney and gall bladder, as well as nervous and immune systems.

Influence of electromagnetic fields of different frequencies and intensities on the growth and development of plants and their root systems occurs differently: some influence is very significant (corn); on the other hand, other does not have significant implications (barley, radish, mustard). Studies conducted by many scientists suggest that EMF may differently affect plant growth, while time of the year, the intensity and frequency of radiation are very important as well [4].

\subsection{Highlight of the unsolved aspects of the problem}

Recent research of effects of electromagnetic radiation on the body of humans and animals indicate a dependence of EMF on: radiated power, antenna system design features, terrain, distance to the source of EMF, etc. [1, 3, 6].

Taking into account all these factors we still have pending question on determining the impact of EMF sources that have a lot of different frequency components. We carried out detailed experimental study of the sources, the results of which can be applied to similar situational conditions.

\subsection{Formulation of the problem}

In this paper, we showed how the electromagnetic radiation affects the environment by the joint application of cellular systems with television, radio broadcasting and radio relay transmitters that are located on the same tower.

\section{Statement of main research data with full justification of scientific results}

Designs of transmit-receive antenna, relay and microwave antennas used in radio transmission systems shall provide adequate coverage of corresponding signal. To do this, they are set at high altitude (sometimes antennas mounted on existing structures, if they are of sufficient height).

To maintain the quality of communication, the signal is directed parallel to face of the earth but the electromagnetic radiation decreases proportional to the square of distance. Signal intensity affecting by artificial and natural obstacles such as trees, buildings, hills, etc.

Therefore, at some distance from the object, level of radio emission is small, and therefore, its impact on the environment is negligible.

We have studied the effect of electromagnetic radiation from antenna systems with joint application of cellular GSM and CDMA standards, television, radio and microwave transmitters, which are located in the tower of the Rivne regional radio transmission center (RRTC) at Antopil village. However, results were taken as the basis of measurement of electromagnetic radiation that was performed by Rivne Regional SanitaryEpidemiological Station of the Ministry of Health of Ukraine during 2006-2011.

Location of antenna television systems, radio transmitters and base stations of mobile operators at this facility is different, both in altitude and for guidance. This approach is used because the radiation patterns in the vertical and horizontal planes are different. To transfer TV signal 5 plots are given in high frequency (HF) and ultra-high frequency (UHF) ranges, and for radio frequency modulation (FM) two frequency lines are using in HF range: $66,74 \mathrm{MHz}$ and $100,108 \mathrm{MHz}$. Technical means of television and radio broadcasting forming EMF radiation due to a strong signal transmitters.

Directional characteristics of emitting equipment in the horizontal plane is much smaller than the vertical expansion of all these parameters together form the so-called "cosecant" radiation pattern, indicating a gradual decrease of the electric field is proportional to the square of the distance from the antenna. Thus, the emitting equipment of television and radio broadcasting to increase the coverage area are located at a height $250 \ldots 300 \mathrm{~m}$, and in some cases even higher, because most of the energy of such radiation is in the main lobe of diagram at distances $100 \ldots 200 \mathrm{~m}$ and the electric field intensity is hundreds of $\mathrm{V} / \mathrm{m}$. With increasing distance from the phase center of the antenna and to the earth's surface the electric field intensity decreases, and in reception area is equal tenths of a $\mathrm{V} / \mathrm{m}$ at the maximum allowable value of $3 \mathrm{~V} / \mathrm{m}$.

The average flux density of the electromagnetic field $S_{\text {ave }}$ is calculated by the formula

$$
S_{\text {ave }}=\frac{8 P G \Phi_{E} F^{2}(\Theta) \eta_{a f t}}{R^{2}}, \mathrm{w} / \mathrm{m}^{2}
$$

where $P$ - radiation power of antenna and feeder, W, $G$ - antenna gain, $\Phi_{E}-$ the impact factor of the Earth $(1,1 \div 1,5), F^{2}(\Theta)$ - value of the normalized Patterns in the relevant direction (azimuth), $\eta_{a f t}$ - efficiency of the antenna-feeder path for signal transmission, $R$-distance from the point of radiation, $\mathrm{m}$.

The radiation power $\mathrm{P}$ of antenna and feeder is given by:

$$
P=P_{\text {nom }} \eta_{a f t}\left(1-\left[\frac{K_{c}-1}{K_{c}+1}\right]^{2}\right), \mathrm{W}
$$

where $P_{n o m}$ - nominal power of transmitter (for TV transmitters the transmitter power of imagery and sound signals should be taken into account).

$$
\left.P_{\text {nom }}=0,327 P_{\text {pict }}+P_{\text {sou }}\right), \mathrm{W}
$$

$K_{c}$-standing wave intensity factor at the antenna input.

As a result of calculations, parameters of investigated electromagnetic fields with different frequency were set (Table 1). At the same time, was set an excess of established maximum

\begin{tabular}{|c|c|c|c|c|c|}
\hline No. & $\begin{array}{l}\text { Channel } \\
\text { name }\end{array}$ & $\begin{array}{c}\text { Frequency } \\
\text { band, } \\
\text { MHz }\end{array}$ & \begin{tabular}{|} 
Density of \\
electromagnetic \\
fields at an \\
altitude of $2 \mathrm{~m}$ \\
from the surface \\
of earth, $\mathrm{W} / \mathrm{m}^{2}$
\end{tabular} & $\begin{array}{l}\text { Intensity of } \\
\text { EMF at an } \\
\text { altitude of } 2 \mathrm{~m} \\
\text { from the cerface } \\
\text { of earth, } \mathrm{V} / \mathrm{m}\end{array}$ & \begin{tabular}{|c} 
Maximum \\
allowable \\
values at a \\
height of $2 \mathrm{~m}$ \\
from the the \\
cerface of \\
earth, $\mathrm{V} / \mathrm{m}$ \\
\end{tabular} \\
\hline 1 & $3 \mathrm{TV}$ & $76-84$ & 0,0013 & $0,7-0,007$ & 4,6 \\
\hline 2 & $10 \mathrm{TV}$ & $206-214$ & 0,0000025 & $0,031-0,001$ & 2,9 \\
\hline 3 & $27 \mathrm{TV}$ & $518-526$ & 0,00047 & $0,42-0,0049$ & 2,0 \\
\hline 4 & $32 \mathrm{TV}$ & $558-566$ & 0,000021 & $0,09-0,0022$ & 2,0 \\
\hline 5 & $37 \mathrm{TV}$ & $598-606$ & 0,0000219 & $0,091-0,0021$ & 2,0 \\
\hline 6 & $39 \mathrm{TV}$ & $614-622$ & 0,00036 & $0,37-0,0025$ & 2,0 \\
\hline 7 & $43 \mathrm{TV}$ & 646-654 & 0,0000095 & $0,06-0,0015$ & 1,9 \\
\hline 8 & $47 \mathrm{TV}$ & $678-686$ & 0,000021 & $0,09-0,0025$ & 1,9 \\
\hline 9 & $49 \mathrm{TV}$ & $694-702$ & 0,000000024 & $0,003-0,0007$ & 1,9 \\
\hline 10 & $51 \mathrm{TV}$ & $710-718$ & 0,0000215 & $0,09-0,002$ & 1,9 \\
\hline 11 & $57 \mathrm{TV}$ & $758-766$ & 0,0000215 & $0,09-0,0021$ & 1,8 \\
\hline 12 & $59 \mathrm{TV}$ & $774-782$ & 0,0000215 & $0,09-0,0025$ & 1,8 \\
\hline 13 & $62 \mathrm{TV}$ & $798-806$ & 0,00001 & $0,062-0,0017$ & 1,8 \\
\hline 14 & $64 \mathrm{TV}$ & $814-822$ & 0,0000095 & $0,06-0,0016$ & 1,8 \\
\hline 15 & $67 \mathrm{TV}$ & $838-846$ & 0,00021 & $0,28-0,0019$ & 1,7 \\
\hline 16 & $\begin{array}{l}\text { UHF, } \\
\text { GSM and } \\
\text { other }\end{array}$ & $900-1800$ & 0,0117 & $2,1-0,17$ & 3,0 \\
\hline
\end{tabular}
allowable values MPL in the vertical component.

Table 1. Defined parameters of electromagnetic field

By measuring the intensity and density of the electromagnetic field, we obtained graph of spectral density of electromagnetic radiation in the range of the meter and decimeter waves (Fig. 1).

This diagram helps to define impact on the environment in the relevant frequency range. It shows that the most significant effect on the electromagnetic field transmitter has a frequency of 900 $\mathrm{MHz}$, ie, UHF, GSM or other channels. Unfortunately, within this study it is impossible to establish exactly the most significant of all existing sources of exposure. Such calculations we plan to conduct in the future, based on the measurement results of specialized tools that will allow us to carry out differential 
frequency analysis of available sources of electromagnetic radiation, as required by the State sanitary norms of Ukraine.

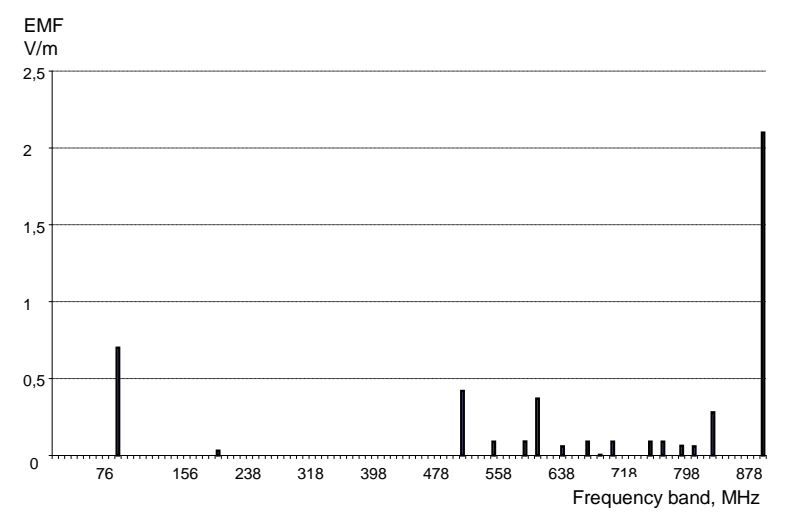

Fig. 1. Spectral density of electromagnetic radiation in the meter and decimeter wavelengths range

As a result of our studies, we obtained total vertical radiation pattern of the antenna systems of TV and radio channels and base stations of mobile operators (Fig. 2). After analyzing the situation around the adjacent area the object being studied, we found that the intensity of electromagnetic fields at a height of $2 \mathrm{~m}$ above the ground and at a distance of $5 \ldots 1000 \mathrm{~m}$ does not exceed maximum permissible levels, but at a height of $16 \mathrm{~m}$ and $550 \mathrm{~m}$ distance from the source of radiation, one can observe and exceed of maximum permissible level of electromagnetic field.

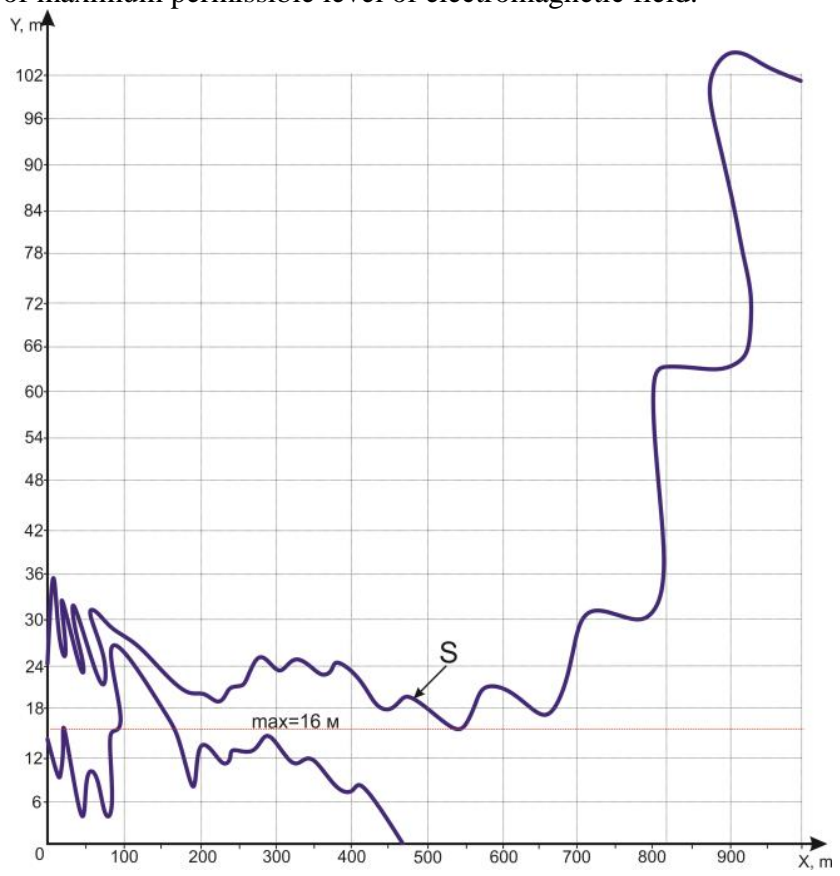

Fig. 2. Maximum level of total electromagnetic load

According to studies, we proposed some recommendations to improve situation with electromagnetic radio and television transmitting center of Rivne city:

- exploit this facility to comply with design standards and passport data corresponding to the performance of the receiving and transmitting equipment, and to avoid their excess even for a short period of time;

- conduct ongoing monitoring of electromagnetic situation around the object;

- involve specialized measurement tools for comprehensive analysis of radiation sources by frequency range, as required by the State health standards;

- local authorities need to limit the use of adjacent areas, especially for construction of housing and other use.

\section{Conclusions}

In summary, it was concluded that the object tested is characterized by a wide range of frequencies and the complicated situation/condition that is characterized by the use of radiation sources with significantly different frequency ranges. Assessment of ra-diation levels was carried out for each channel separately, which greatly complicates the process of research, because each has its own range of frequencies has its own permissible level defined by a specific standard. A common use of relaying tower in Rovno for retransmission of television and radio channels signals and mobile opera-tors complicates the electromagnetic environment. To carry out comprehensive moni-toring of the electromagnetic state use specialized measuring tools has to be applied so as to help analyze the frequency of various sources of radiation, in accordance with the requirements of the state standards of Ukraine. During the observations a high rate of energy flux density of $3,86 \ldots 5.9 \mathrm{~W} / \mathrm{m} 2$ in the $900 \mathrm{MHz}$ range has been reported, which may indicate to incompatibility of passport parameters of individual radiation sources or abnormal conditions of operation of the sending-receiving equipment. Taking the above into account, the electromagnetic state of the test object requires constant monitoring and further detailed studies.

\section{References}

[1] Bezverkhaya A.P.: Gigiyenicheskaya otsenka vliyaniya elektromagnitnogo izlucheniya na organizm cheloveka i zhivotnykh. - Gigiena naselenikh mists: Zb. nauk. prats. DU «IGME AMNU». Vip. 53. Kiïv. 2009, s. 228-231.

[2] Derzhavni sanitarni normi i pravila zakhistu naselennya vid vplivu yelektromagnitnikh viprominyuvan. DSNiP №239-96 vid 01.08.96r., m.r. №4550/88.

[3] Grudziński E., Nichoga V., Antonyuk V., Prudyus I.: Monitoring źródeł pól elektromagnetycznych $\mathrm{w}$ diagnozowaniu zagrożeń dla środowiska. Przegląd Elektrotechniczny. 2009, R. $85 \mathrm{nr} 11$, s. 105-110.

[4] Kovaleva A.V.: Vliyaniye elektromagnitnykh poley i izlucheniy na bioobyekty, Zaporizkiy Natsionalniy Universitet. Z., 2009, s. 64-85.

[5] Naumchuk A.O., Safonov R.V., Yarmolyuk T.I., Naumchuk O.M.: Vpliv elektromagnitnogo viprominyuvannya bazovikh stantsiy stilnikovoï telefoniï GSM standartu., Bezpeka pratsi: Naukovo-virobnichiy zhurnal. Vip. 1., Rivne. 2011, s. 17-19.

[6] Nikitina N.G., Barkevich V.A.: Vpliv elektromagnitnikh viprominyuvan na zdorov'ya naselennya (naukoviy oglyad). Gigiena naselenikh mists: $\mathrm{Zb}$. nauk. prats. DU «IGME AMNU». Vip. 50. Kiïv. 2007, s. 209-214.

[7] WHO handbook on Establishing a Dialogue on Risks from Electromagnetic Fields http://www.who.int/peh-emf/publications/riskrussian/en/index.html\#

[8] Kholodov Yu.A.: Mozg v elektromagnitnykh polyakh. M.: Nauka, 1982, s 123.

[9] http://www.euro.who.int/_data/assets/pdf_file/0008/74465/E89486R.pdf.

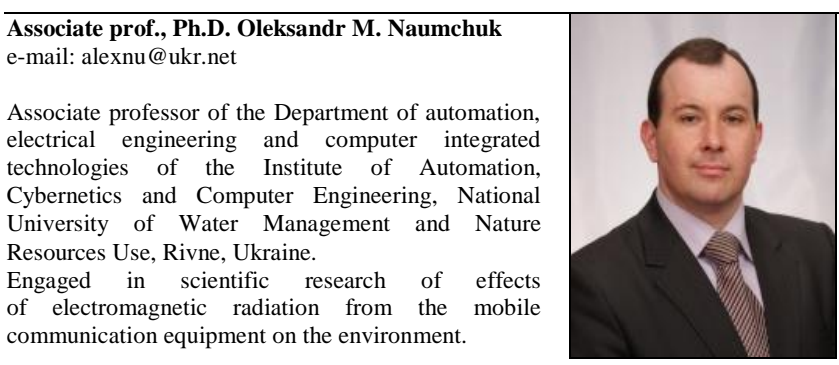

otrzymano/received: 28.09 .2013

przyjęto do druku/accepted: 30.11 .2013 